\title{
Analisis Arkeobotani Dalam Penelitian Arkeologi
}

\section{Siswanto}

Keywords: biology, botany, plant, pollen, phytolith, methods, theory, practices, analysis

\section{How to Cite:}

Siswanto, nfn. (2000). Analisis Arkeobotani Dalam Penelitian Arkeologi. Berkala Arkeologi, 20(1), 40-46. https:/ / doi.org/10.30883/iba.v20i1.805

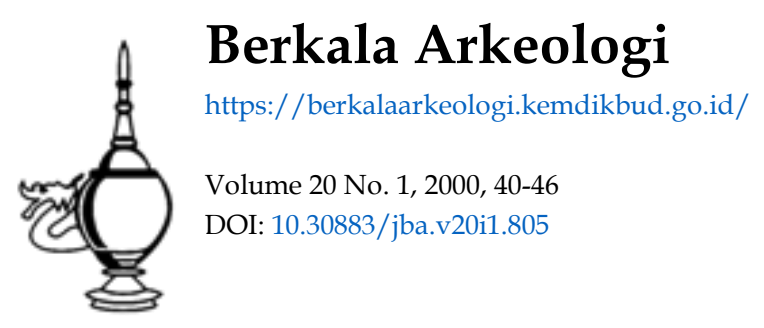

\section{(c) (1) (2)(2)}

This work is licensed under a Creative Commons Attribution-NonCommercial-ShareAlike 4.0 International License. 


\title{
ANALISIS ARKEOBOTANI DALAM PENELITIAN ARKEOLOGI
}

\author{
Siswanto \\ (Balai Arkeologi Yogyakarta)
}

\section{Pendahuluan}

Pada umumnya temuan sisa biotik dalam penelitian arkeologi didominanasi temuan berupa sisa hewan seperti tulang, tanduk, cangkang, karapak, dan gigi. Hal ini terjadi karena sisa hewan tersebut mengandung unsur kapur yang tahan terhadap proses dekomposisi. Sebalikya unsur yang dikandung tumbuhan mudah rusak dan hancur karena mudah terurai (dekomposisi). Hanya dalam keadaan tertentu sisa tumbuhan dapat terawetkan seperti tersimpan pada suhu rendah atau pada bahan/meteri yang langka jasat renik, atau pada proses pengendapan secara tiba-tiba sebelum sisa tumbuhan tersebut hancur sehingga dari proses ini kemudian meninggalkan tapak atau jejak. Dalam bentuk apapun temuan sisa flora dari bagian akar, batang, cabang, ranting, daun, buah, biji, pollen, pitholyths, dan lainnya semua bermanfaat karena yang diperlukan adalah informasi yang terkandung di dalamnya. Dari bagian-bagian tumbuhan tersebut yang bermacam-macam ukuran, bentuk serta cara penanganannya maka dibedakan menjadi dua yaitu temuan mikroskopis dan temuan makroskopis. Sedangkan bentuk dan cara analisis temuan flora dalam studi arkeologi tidak hanya dari materi sisa flora alamiah saja, namun dapat berupa indikasi bentuk-bentuk flora hasil karya manusia seperti relief, patung, maupun gambar. Walaupun temuantemuan semacam ini merupakan hasil karya rekaan manusia namun proses identifikasinya tetap menggunakan prinsip-prinsip botani, bila perlu dengan referensi yang terkait. Apapun hasilnya diharapkan menghindari analisis atau identifikasi temuan berdasarkan intuitif saja.

\section{Bentuk-bentuk Temuan Flora dalam Penelitian Arkeologi}

\section{A. Temuan Mikroskopis}

\section{Pollen}

Metoda ini suatu cara memperoleh informasi pada tumbuhan tingkat tinggi (phanerogamae) atau tumbuhan berbunga. Pollen atau serbuk sari bunga memiliki bahan silika yang tidak mudah terurai (dekomposisi) sehingga dapat bertahan (awet) di dalam tanah. Metoda analisis pollen dikembangkan oleh ahli botani dari Swedia Lennart Van Post, dimana metoda ini telah terbukti dapat memeberikan manfaat bagi bidang penelitian arkeologi terutama penyediaan informasi vegetasi, iklim dan bahkan 
kronologi masa lalu (Shackley, 1981). Sedangkan Dimbleby (1969) menyatakan tentang keguanaan analisis pollen dalam penelitian arkeologi antara lain untuk pengungkapkan kembali lingkungan masa lampau dan penentuan pertanggalan. Pengungkapan lingkungan masa lalu dimaksud ialah lingkungan flora atau vegetasi lingkungan, sedangkan dalam penentuan pertanggalan dengan analisis pollen ialah penentuan pertanggalan secara relatip yaitu dengan membandingkan flora yang terdapat di suatu tempat dengan flora yang telah dikenal di tempat lain. Penerapan analisis pollen untuk kronologi yang paling cocok adalah untuk kala post glasial atau holosen.
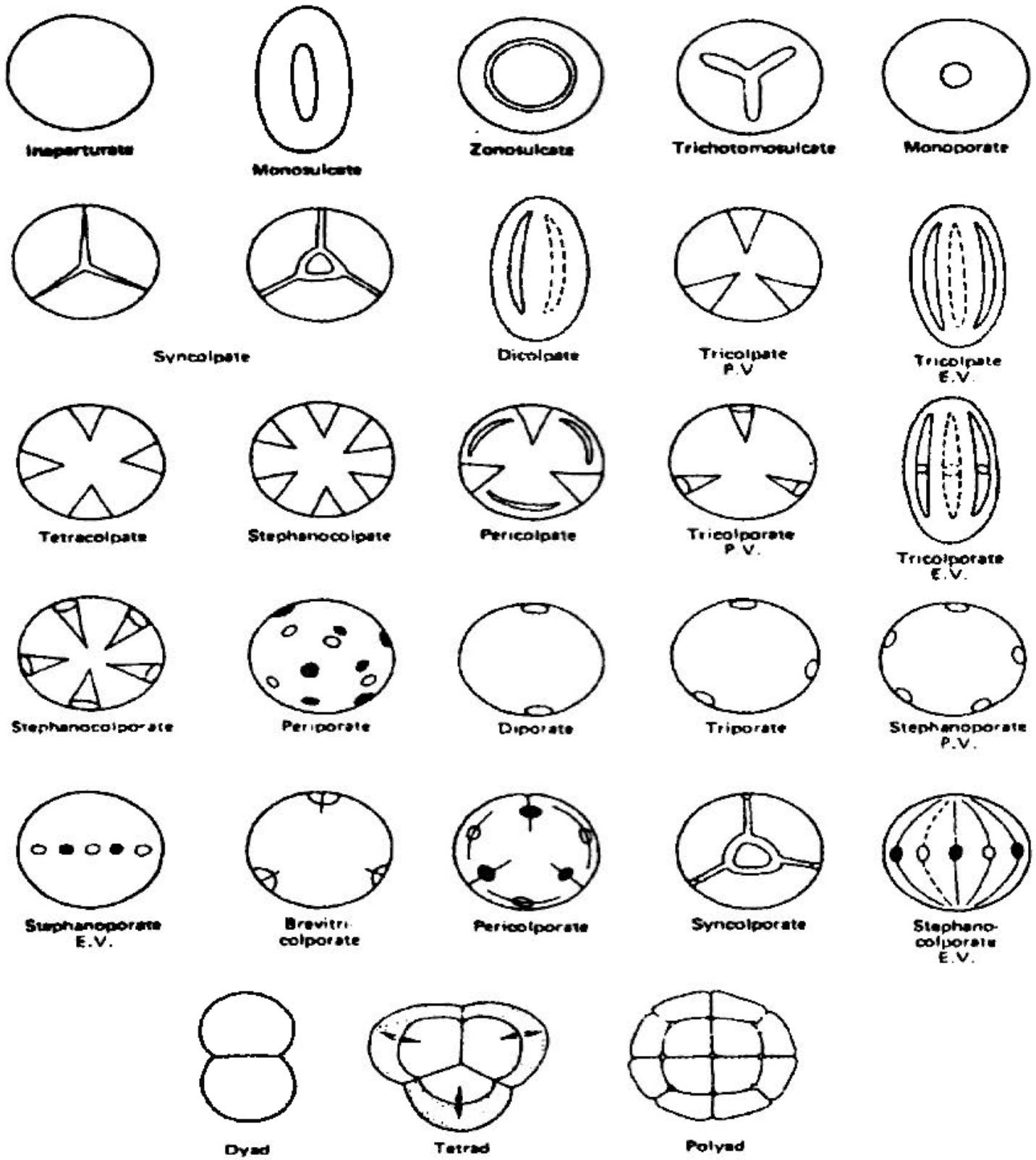

Gambar 1. Contoh macam-macam tipe pollen 

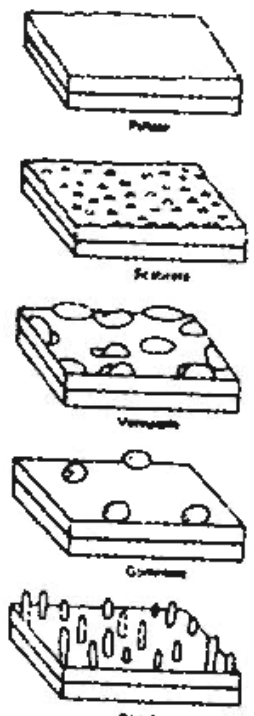

$\operatorname{lin}$
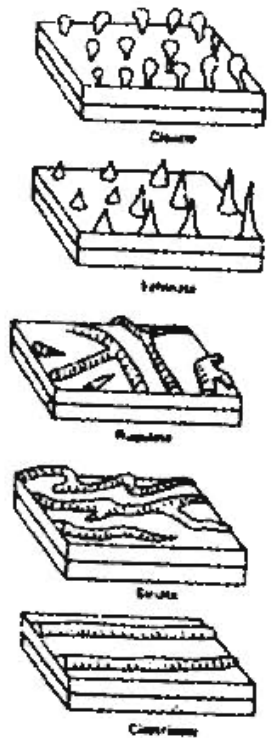
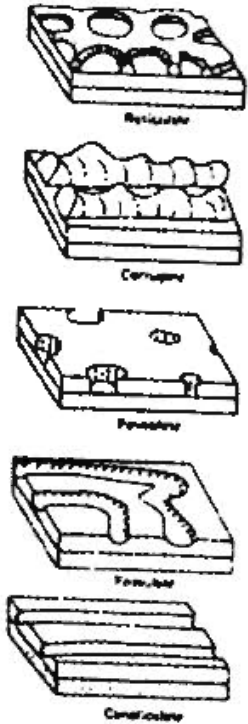

Gambar 2. Contoh macam-macam dinding pollen (Scott, 1969)

\section{Diatom}

Metoda lain dalam rekonstruksi lingkungan adalah dengan menggunakan mikrofosil tumbuhan yaitu analisis diatom (Renfrew \& Bahn, 1991). Diatom atau diatomae (Bacillariopphyceae) adalah tumbuhan tingkat rendah atau alga ber sel tunggal (uniseluler) yang hidup diperairan air tawar, air payau maupun air laut (Evans, 1978). Alga kersik ini hidup melimpah di perairan laut maupun tawar mempunyai arti penting sebagai sumber pakan utama ikan dan hewan laut dan tawar. Algae ini mempunyai diding sel dari bahan silika sehingga dinding sel ini bertahan setelah algae nya mati. Bila alga ini terurai atau dicerna oleh hewan dinding selnya tidak menjadi busuk, tetapi dalam jumlah yang besar tenggelam ke dasar air membentuk suatu endapan yang biasa disebut "tanah diatomae" yang sangat luas (Polunin, 1990). Proses identifikasi dan perhitungan dalam preparasi menggunakan teknik seperti dalam analisis pollen.

\section{Phytoliths}

Analisis phytoliths ini pada prinsip pelaksanaannya seperti halnya metoda analisis pollen, karena bagian tumbuhan ini biasanya ditemukan dengan bentuk sangat kecil antara 20 - 50 mikron (Schiffer, 1983). Phytoliths adalah bagian dari partikel silika yang berasal dari sel tumbuhan, bagian ini dapat bertahan setelah organisme itu mati dan tidak terdekomposisi atau terbakar. Beberapa contoh dalam penelitian arkeologi pada umumnya terdapat pada tungku (bekas perapian) atau lapisan abu, tetapi juga ditemukan pada keramik, plester dan bahkan tersisa pada alat batu maupun pada gigi herbivora ( Renfrew \& Bahn, 1991). Kombinasi analisis phytoliths dengan analisis pollen merupakan sarana yang kuat untuk merekonstruksi lingkungan kuna. 
Analisis phytoliths dan analisis diatom ini dalam penelitian arkeologi Indonesia belum banyak operasional bahkan masih sebatas gagasan baru, untuk operasionalnya perlu langkah uji coba dan studi khusus.

\section{B. Temuan Makroskopis}

\section{Daun}

Pada umumnya daun alami yang ditemukan dalam penelitian arkeologi berupa cetakan daun atau tinggal jejaknya saja sedangkan daun yang tidak alami berupa gambar dan relief. Analisis daun ditujukan untuk memperoleh jenis tumbuhannya dengan memperhatikan ciri-ciri morfologis, karena dengan ciri lain sangat sulit bahkan tidak dimungkinkan didapatkan seperti ciri warna dan ketebalan daging daun.

\section{a. Perekaman temuan dan identifikasi:}

Ciri morfologis daun yang dapat dicatat meliputi: jumlah daun, bangun daun, ujung daun, pangkal daun, susunan tulang daun, bentuk tepi daun, dan permukaan daun. Analisis morfologis temuan daun tersebut dengan menggunakan prinsip-prinsip analisis botani, yang dipakai untuk analisis baik jejak daun, gambar maupun relief, adapun contoh formulir untuk analisis dengan data isian seperti pada lampiran. Setelah seluruh data ciri-ciri daun tersebut direkam maka langkah berikutnya yaitu sedapat mungkin identifikasi melalui cara perbandingan dengan tumbuhan yang diasumsikan sejenis dan perlu diperkuat dengan tinjauan literatur.

\section{b. Pengemasan dan penyimpanan:}

Temuan dalam bentuk cetakan daun ada yang dapat dipindahkan dan ada yang tidak dapat diangkat (dipindahkan), hal ini tergantung pada kondisi tempat temuan, berada pada tanah yang lapuk atau pada tanah yang kompak dan keras. Apabila temuan berada pada materi yang memungkinkan untuk diangkat maka pengemasannya dengan memisahkan dari tempat asalnya, sedangkan bila tidak memungkinkan dapat dilakukan denga membuat cetakan bada bahan gib, karet, atau pada vinyl.

\section{c. Pengawetan:}

Untuk menghindari kerusakan cetakan daun setelah dibersihkan dan telah nampak bentuk daunnya maka perlu pengawetan, disamping itu bila materi cetakan daun yang dapat dipindahkan namun tidak kompak juga perlu bahan pengawet atau penguat. Bahan pengawet yang diharapkan tidak merubah keaslian temuan dan disarankan menggunakan PVA (pollyvinyl acetat) dengan pelarut alkohol $90 \%$ maupun dengan aceton. 


\section{Kayu dan Arang}

Temuan kayu merupakan bagian dari pohon berasal dari bagian batang, ranting, dan cabang pada umumnya dalam bentuk artefak yaitu berupa bahan bangunan, alat, bagian dari kapal maupun perahu, selain itu kayu biasanya ditemukan dalam bentuk fosil dan arang. Informasi yang diperlukan pada temuan artefak dari bahan kayu terutama jenis pohon/tumbuhannya, umur (pertanggalan), dendrokronologi, iklim, teknologi dan bahan bangunan. Penentuan jenis tumbuhan berdasarkan temuan kayu belum ada teknis baku, hanya dengan cara koleksi kayu sebanyak-banyaknya sebagai referensi. Cara identifikasi secara kasar melalui pengamatan fisik yaitu berdasar kekerasan kayu, dibedakan jenis tumbuhan berdaun jarum pada umumnya berkayu lunak dan tumbuhan berdaun lebar umumnya berkayu keras. Penentuan umur atau pertanggalan dimaksud yaitu pertanggalan yang berkaitan dengan perriodisasi budaya di situs dimana ditemukan kayu, pertanggalan dengan bahan (sampel) kayu ini sering dilakukan dengan metoda radiokarbon (C14). Dendrokornolgi dan iklim yang akan diperoleh informasinya dari temuan kayu berhubungan dengan lingkaran pohon, apabila pohon (kayu) dipotong horozontal maka akan tampak lingkaran-lingkaran pohon. Lingkaran-lingkaran tersebut bisa disebut lingkaran tahun --yaitu garis pertumbuhan-- yang berarti pohon tersebut dalam pembentukan satu lingkar diperlukan selama satu tahun. Untuk pengamatan iklim tinggal mengamati tebal dan tipisnya lingkarannya, karena di Indonesia hanya dikenal dua musim yaitu kemarau dan hujan maka dalam satu lingkaran pohon akan nampak lapisan tebal untuk musim hujan dan lapisan tipis untuk pertumbuhan pada musim kemarau.

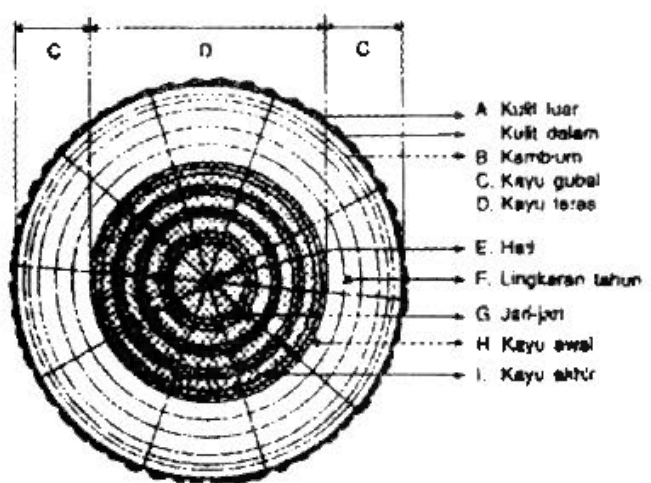

Gmb. 3. Penampang kayu

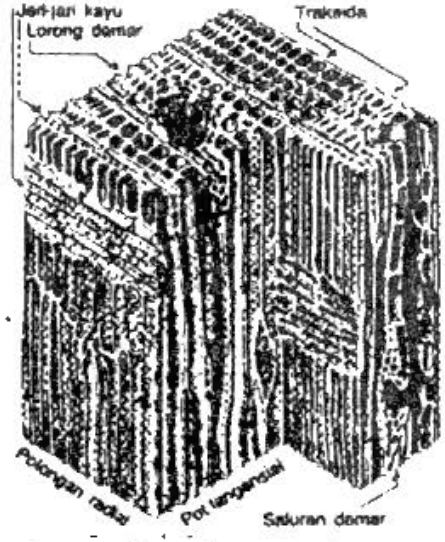

Gmb. 4. Struktur sel kayu berdaun jarum

(sumber : Dumanauw, 1990)

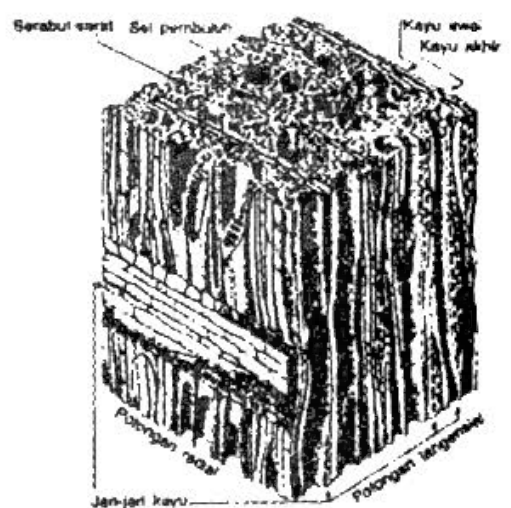

Gmb. 5. Struktur sel kayu berdaun lebar

\section{a. Perekamam temuan:}

Selain mengisi data umum untuk temuan kayu maupun arang --seperti dalam lampiran struktur data-base-- hal yang penting untuk dicatat pada temuan kayu adalah ciri-ciri morfologisnya yaitu: diameter, diukur menggunakan busur untuk pengukuran keramik maupun gerabah, pengukurannya berdasarkan besarnya lengkungan lingkaran pohon. 
Kemudian ada maupun tidak adanya kulit, gubal, dan teras dicatat apa adanya sesuai kondisi temuan. Pengukuran tekstur kayu ada tiga katagori yaitu 1) halus, (contoh: kayu giam, lara, kulim), 2). sedang (contoh: kayu jati, sonokeling, dll), 3). kasar (contoh: kayu kempas, meranti, dll). Parameter kekerasan dikatagorikan menjadi empat yaitu; 1). Sangat keras (contoh: kayu balau, giam, dll.), 2). Kayu keras (contoh: kayu pulim, pilang), 3). Kayu sedang (contoh: kayu mahoni, meranti), Kayu lunak (contoh: kayu pinus, balsa, alba, waru dll). (Dumanau, 1990).

\section{b. Pengemasan dan Penyimpanan:}

Sebelum dikemas dan disimpan temuan kayu maupun arang terlebih dahulu temuan tersebut dalam keadaan bersih dan kering, jenis kemasannya disesuaikan dengan besar kecilnya temuan dan kemungkinan diadakan analisis lebih lanjut. Temuan dalam bentuk dan jumlah besar cukup dikemas dengan plastik, tetapi bila dalam jumlah sedikit dan perlu analisis lebih lajut misalnya untuk sampel pertanggalan radiokarbon maka perlu dikemas dalam aluminitum foil maupun bahan lain sejenis

\section{c. Pengawetan:}

Dalam kondisi apapun dari temuan ini apabila akan dilakukan analisis lanjutan misalnya analisis pertanggalan radiokarbon, temuan tidak perlu dilakukan pengawetan dengan bahan apapun karena justru akan mengganggu analisis. Bahkan dalam pembersihan pun tidak dianjurkan dengan menggunakan air maupun bahan cair lainnya. Tetapi bagi temuan kayu yang berupa artefak dan tidak perlu analisis lajutan maka dapat dilakukan pengawetan untuk mencegah pelapukan maupun serangan serangga. Pengawetan dengan pengolesan atau penyuntikan bahan fungisida (anti jamur) maupun insektisida (anti serangga) maupun bahan lain yang disesuaikan dengan keadaan temuannya.

\section{Buah/biji}

Buah maupun biji jarang sckali ditemukan secara langsung dalam penggalian dalam penelitian arkeologi, karena bendanya yang kecil ringan dan rapuh seringkali ditemukan dalam ayakan maupun dalam pengapungan (flotation). Perolehan temuan dengan cara pengapungan (froth flotation) sementara merupakan metoda yang paling praktis dan mudah untuk memperoleh biji maupun buah, karena biji maupun buah yang telah lama tersimpan dalam tanah akan mudah mengapung di permukaan air. Cara pengayakkan masih bisa lolos bagi biji yang ukurannya dibawah ukuran ayakan, disamping itu bagi biji atau buah yang rapuh akan hancur atau rusak pada saat pengayakan.

Temuan biji atau buah sebagaimana temuan sisa flora lainnya bahwa informasi yang diperlukan adalah jenis tumbuhan dan mencatat segala atribut fisik lainnya. Untuk tahapan selanjutnya tergantung kepentingan lanjutan apakah disimpan atau akan dipakai bahan sampel analisis lainnya (pertanggalan). 


\section{Penutup}

Temuan sisa flora dalam bentuk apapun untuk studi arkeologi pada umumnya akan dikaitkan langsung dengan manusia masa lalu, yaitu mengenai sumber pangan, pembudidayaan tanaman atau budaya bercocok tanam, dan teknologi. Selebihnya berkaitan dengan masalah lingkungan dan vegetasi masa lalu (arkeo-ekologi), kepentingan pertanggalan, klimatologi, dan lainnya. Sehingga cara penanganan temuan sisa flora disamping menyesuaikan jenis temuannya juga menyesuaikan kepentingan informasi apa yang diharapkan. Teknik dan metoda penanganan temuan sisa flora telah banyak dikembangkan oleh para ahli, namun di lingkungan Puslit Arkenas belum dimanfaatkan secara maksimal, hal ini disamping keterbatasan sumberdaya manusia juga berkaitan dengan perangkat penunjangnya. Upaya untuk mengatasi kekurangan bisa dilakukan melalui kerjasama dengan pihak luar, sepanjang penanganan temuan (analisis) sisa flora yang tidak atau belum bisa dilakukan sendiri.

\section{KEPUSTAKAAN}

Dimbleby, Geoffrey. 1978. Plant and Archaeology. Paladin Granada Publishing, London, Toronto, Sidney, New York.

Dumanau, J.F. 1990, Mengenal Kayu. Kanisius. Yogyakarta.

Evans, John G. 1978, Environmental Archaeology. Paul Elek. London.

Lawrence, George H.M. 1968. Taxonomy of Vascular Plants. The Macmillan Company, New York. Collier-Macmillan Canada, Ltd., Toronto, Ontario.

Polunin, Nicholas, 1990. Geografi Tumbuhan (Terjemahan oleh: Gembong Tjitrosupomo, Editor: Wibisono Soerodikoesoemo). Gadjah Mada University Press. Yogyakarta

Renfrew, Colin \& Bahn, Paul. 1991. Archaeology - Theories, Methods and Practice. Thames and Hudson Ltd. USA.

Schiffer, M,B. (Editor). 1983. Arhaeological Method and Theory. Academic Press, New York, London.

Scott, Richard A. and Tschudy, Robert H. 1969. Aspects of Palynology - An Introduction to Plant Microfossils in Time. Wiley-Interscience. A Division of John Wiley \& Sons. New York. London. Sydney. Toronto.

Shackley, M. 1981. Environmental Archaeology. George Allen \& Unwin, London, Boston, Sydney. 